\title{
EFFECT OF ENDOSULFAN ONENZYME ACTIVITY IN SOME AQUATIC ORGANISMS
}

\author{
KALPANA KULKARNI
}

Yeshwant Mahavidyalaya, Wardha, M.S., India

ashirwad.kalpana@gmail.com

\begin{abstract}
:
The extensive and indiscriminate use of economic poison (pesticide) has resulted in their entrance into the ecosystem affecting different species in the aquatic environment. Proteins are important biomolecules involved in wide spectrum of cellular metabolic function. The indiscriminate use of organochlorine pesticide causes deleterious effect or even death to aquatic organisms. The physiological and biochemical alternations observed inanimals with pesticide stress can correlate with structural and functional changes of cellular proteins. Majority of enzyme catalyzed reactions takes place within the living cells. Enzyme bioassays can provide diagnostic means to assess damage or injury caused to organism due to exposure to harmful substances. Effect of endosulfan on enzymes protease, Glutamate dehydrogenase (GDH), Aspartate aminotransferase (AAT) and Alanine aminotransferase (AIAT) were analyzed in this study. The crab $\underline{P}$. jacquemontii, fish $\mathrm{C}$. orientalis, $\underline{B}$. bengalensis exposed to endosulfan showed variations in enzymes protease, glutamate dehydrogenase, aspartate amino transferase and alanine amino transferase activity levels at 24, 48, 72 and $96 \mathrm{~h}$ treatment period. The freshwater crab p. jacquemontii, fish c. orientalis, B. bengalensis showed variations in activity exposed to lethal and sub lethal concentration of endosulfan at different time intervals. Results of present study at lethal of concentrations of endosulfan showed general increase in enzyme activity (protease, glutamate dehydrogenase, aspartate amino transferase, alanine amino transferase) at 24, 48, 72 and 96 hours, except in fish, in which declined enzyme levels were observed at $24 \mathrm{~h}$ treatment period, which suggested synthesis of protein at early exposure period.
\end{abstract}

Key words: - Organochlorine, Enzyme activity, Lethal, Biomolecules

\section{INTRODUCTION:}

Pesticides released into the environmenthas imbalanced the biology of ecosystem (Holden, 1973). Furthermore pesticides carried through food chains are very harmful to the aquatic animals and a potential danger to man when he consumes. The inhibitory effect was observed in Lepomis macrochirus, Labeo rohita, Danio rerio, and Jenynsia multidentata exposed to endosulfan (Ballesteros et al. 2009; Kumar et al. 2012;) Entry of these pesticidesinto water bodies through industrial effluents, run off of direct applications affects many aquatic organisms (Kulkarni and Tankar, 1984 a.
Sherekar, 1986: Kabra, 1988; Malu, 1989).The pest controllers and weed-killers are moderately to highly toxic to aquatic invertebrates such as crab, shellfish and fish species (Narra et al., 2012).

Proteins as most important constituents of the animal tissue and amino acids as the building blocks of proteins have an important role to play in cellular metabolism. As enzymes, proteins participate in the intricately balanced subcellular functions. Since enhanced proteolysis causes major alteration in nitrogen metabolism, it was felt necessary to investigate comparative protease activity in tissues. The 
enzyme aspartate aminotransferase catalyzes the interconversion of aspartic acid and keto glutamic acid to oxaloacetic acid and glutamic acid, whereas alanine and aminotransferase catalyzes the interconversion of alanine and ketoglutaric acid to pyruvic acid and glutamic acid. Aminotransferases functions at the junction between carbohydrate and protein metabolism by interconverting the strategic compound ketoglutarate, pyruvate and oxaloacetate. On one side alanine aspartic acid and glutamate on the other.The enzyme glutamate dehydrogenase catalyses the reversible oxidative deamination of glutamate to ketoglutarate and ammonia with pyridine nucleotide as a co-enzyme. This reaction serves as a link between protein metabolism and carbohydrate metabolism. MacKim et al (1970) reported an increase in blood AAT activity in Salvelinus fontinalis when exposed to short term copper toxicity.Many workers have observed inhibition of different enzymes due to exposure to metals (Satapathy et al., 1988; Shaikh and Bhagwat 1988; Katti and Sathyanesan, 1986; Choudhary, 1987).Bakthavathsalam and Reddy (1982), reported effect of Lindane on the enzyme activities of Anabas testudineus several workers have reported ALAT, AAT activities in different animals. Kabeer Ahmed (1981) studied in Tilapia mossambica. Ravinde Reddy (1985) reported ALAT, AAT, GDH activity in freshwater mussels Parresysia rugosa exposed to mercury and copper. Venkateswaralu (1988) observed GDH activity in fish Clarias batrachus exposed to endosulfan.

\section{MATERIAL \& METHODS:}

The test animals crab P. jacquemontii, fish. C. orientalis and the snail $\mathrm{B}$. bengalensis were procured from Fish Market and local pond. Methods used for different enzyme analysis of endosulfan exposed selected aquatic organisms are

\begin{tabular}{|l|l|l|}
\hline S.No & Enzyme & Method \\
\hline 1 & Protease & $\begin{array}{l}\text { Moor and } \\
\text { Stein, (1957) }\end{array}$ \\
\hline 2 & $\begin{array}{l}\text { Glutamate } \\
\text { dehydrogenase } \\
\text { (GDH) }\end{array}$ & $\begin{array}{l}\text { Loe and } \\
\text { Landy, (1965) }\end{array}$ \\
\hline 3 & $\begin{array}{l}\text { Aspartate } \\
\text { aminotransferase } \\
\text { (AAT) }\end{array}$ & $\begin{array}{l}\text { Reitman and } \\
\text { Frankel } \\
(1957)\end{array}$ \\
\hline 4 & $\begin{array}{l}\text { Alanine } \\
\text { aminotransferase } \\
\text { (AIAT) }\end{array}$ & $\begin{array}{l}\text { Reitman and } \\
\text { Frankel } \\
(1957)\end{array}$ \\
\hline
\end{tabular}

\section{RESULT AND DISCUSSION:}

The crab p. jacquemontii, fish c. orientalis, snailB. bengalensis exposed to endosulfan showed variations in enzymes protease, glutomate dehydrogenase, aspartate aminotransferase and alanine aminotransferase activity levels at 24, 48, 72 and $96 \mathrm{~h}$ treatment period. Hepatopancrease/Liver being an important organ is selected for protease, GDH, AAT, ALAT estimation. Crab, fish and snails enzyme activity was studied after endosulfan exposure.

\section{Protease activity.}

$\underline{\text { P. jacquemontii : Protease activity increased }}$ from $1.23,1.41,1.51$ to 1.61 for lethal treatment and from $1.20,1.38,1.49$ to 1.58 for sublethal treatment.

C. orientalis : Lower activity of protease was observed at $24 \mathrm{~h},(-8.27)$ which further increased from 39.26 to 56.18 treatment period. and 69.33 percent at 48, 72 and $96 \mathrm{~h}$ treatement period. For sublethal treatment values changed from -6.89 to $37.30,54.08$ to 66.72 .

B. bengalensis: Protease activity was seen to be increased throughout the experimental period. Values ranged from 1.12 to 1.47 for lethal and 1.08 to 1.46 for sublethal effect of endosulfan.

(Refer Table 1.1)

\section{Glutamate dehydrogenase}

P. jacquemontii : In crab treated to endosulfanglutamate dehydrogenase activity showed trend. Values were in increasing order 
up to $96,2.60,2.86,3.17,3.36$ and $2.57,2.84,3.13,3.32$ were corresponding values for lethal and sublethalconcentrations.

C. orientalis : Glutamate dehydrogenase activity was decreased upto $24 \mathrm{~h}$ and thereafter increased upto $96 \mathrm{~h}$. The changed percent activity for lethal was - 801411157696532 and for sublethal $-6.23,39.22,55.62,63.29$ at 24 , 48, 72 and 96 h exposure period.

B. bengalensis : Enhanced activity was observedafter endosulfan treatment, at 24, 48, 72 and 96 h. During lethal treatment values range between 0.71 and 0.90 and between 0.70 and 0.90 at sublethal treatment. (Refer Table 1.2)

\section{Aspartate aminotransferase}

P. jacquemontii:The AAT activity was beginning upto increasing from the experiment. At the end of seen the Changes in percent values were 21.69, 37.67, 46.78, 51.29 for lethal and 18.64, 39 61, 40.72, 49.04 for sublethal endosulfan exposure.

C. orientalis : The activity was less upto $24 \mathrm{~h}$, then the activity was increased upto last exposure period i.e. 96 hour. Variations in values were $2.06,3.13,3.46,3.69$ for lethal and $2.09,3.08,3.36$ and 3.62 for sublethal treatment.

B. bengalensis : The percent elevations in AATactivity were from 15.98 to 48.69 for lethal and from 14.92 to 46.63 for sublethal endosulfan treatments. (Refer Table 1.3)

\section{Alanine aminotransferase}

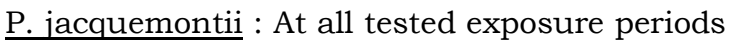
the activity was higher than the control. Activity for Lethal concentration ranged from 3.87 to 4.84 and from 3.83 to 4.79 for sublethal concentration.

C. orientalis: In endosulfan exposed fishes. low activity was recorded at $24 \mathrm{~h}$ which thereafter was increased up to $96 \mathrm{~h}$. Recorded values 8.02, 41.27, 55.36,67.09 and -7.89, 39.22, $53.16,66.28$ were percent changes after lethal and sublethal treatment.
B. bengalensis: Similar results were observed as that of crab. Activity ranged from 3.45 to 4.37 and3.39 to 4.29 for lethal and sublethal exposure.

\section{(Refer Table 1.4)}

The freshwater crab $\mathrm{p}$. jacquemontii, fish $\underline{\mathrm{c}}$. orientalis, snail B. bengalensisshowed variations in activity exposed to lethal and sublethal concentration of endosulfan at different time intervals. Results of present study at lethal and sublethal concentrations of endosulfan showed general increase in enzyme activity (protease, glutamate dehydrogenase, asparatate amino transferase, alanine amino transferase) at 24, 48, 72 and 96 hours, except in fish, in which declined enzyme levels were observed at $24 \mathrm{~h}$ treatment period.

In crab $\underline{P}$. jacquemontii all enzyme levels were be increased after lethal and sublethal concentrations of endosulfan. The protease enzyme functions in the breakdown of proteins leading to the formation of free amino acids at neutral pH. Glutamate dehydrogenase catalyzed oxidative deamination of glutamate to ammonia and ketoglutarate. It notonly channels the nitrogen from glutamate to ammonia but also catalyzes the animation of keto glutamate to free ammonia. Sumati et al(1989) observed the increased GDH, ALAT and AAT activities in crab Oziotelphusa senex senex exposed to endosulfan. Present study results arein agreement with the above study: This Increased GDH activity attributed to increased oxidation of glutamate, since GDH catalyzes the key reactions which provide substrates for protein synthesis. Increased AAT, ALAT content might suggest the increased oxidation of glutamate for sustained generation of ketoglutarate. Amino transferase activity acts as the intermediary point between carbohydrate and proteinsbyinterconverting strategic crossover in metabolites like ketoglutarate, pyruvate and oxaloacetate, and 
other side alanineaspartate and glutamate. The increased activity levels of AAT and ALAT may be due to tissue damage or disruption of mitochondrial integrity or may be the result of increased synthesis of enzyme. Similar reports were observed in crab $\underline{O}$. senex senex exposed endosulfan (Sumati et al ,1989). Increased AAT ALAT activitieswere noticed with pesticide stress (Swani et al. 1983; Srinivasulu Reddy et al., 1985) on mussel and prawn.

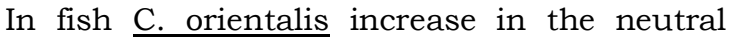
protease activity was progressive with the progression directly proportional to the exposure period. The rise in activity was more at lethal as compared to sublethal concentration. The protease were known to breakdown proteins to small peptides and ultimately to amino acid. Protease activity and free amino acid levels were found to be maximum in liver tissue, least ingills and intermediary in muscle. It clearly indicated that tissue, pesticide favoured protein breakdown by inducing protease activity which lead more free amino acid synthesis or production. Thus pesticide creates metabolic as proteins have dynamic role to play the tissue metabolism. Resultsin present study are in consistent withChoudhary (1987) in fish $\underline{\mathrm{R} \text {. daniconius }}$ exposed to BHC and malathion. Similar increase in protease activity was recorded by Kabeer et al Dikshit et al (1975). Decrease in protease activity at early hour exposure may be due to synthesis of protein.In fish C. orientalis aspartate amino transferase and alanine aminotransferase levels were more pronounced in liver. Increased AAT and ALAT activity may be due to more conversion of amino acid in to ketoacids to be utilized for energy synthesis. Aminotransferase showed that the tissue seen to favour more pyruvate formation over oxaloacetate and this might be associated with the metabolic needs of respective tissue.Liver showed remarkable elevation in ALAT activity as compared to AAT activity. Since liver vas the seat of metabolism and contain fuel complement of all enzymes concerned with carbohydrate metabolism; pyruvate formed through ALAT activity may be converted to acetyl coenzyme to mobilized by the TCA cycle. Increased activity in liver may be, to compensate the low activity level in other tested tissue.

Increased protease activity in snail B. bengalensis suggested possible degradation of proteins (Sivaprasad Rao et al., 1980; Rajeshwara Rao et al., 1983). Alterations in the fatty acid profile, antioxidant enzymes and protein pattern of Biomphalariaalexandrina snails exposed to the pesticides diazinon and profenofos..( Bakry et.al. 2013)GDH activity which is regulatory link between energy and nitrogen metabolism was and increased significantly. This results in increased formation of keto glutamate and it's utilization in transamination. Enhanced AAT and ALAT activities might be due to imposition of stress on the animal during pesticide exposure. It has been suggested that the stress condition in general induced an elevation in the activities of transaminase (Knox et al., 1965; Kulkarni et al., 1973). It is likely that the toxic stress could be responsible for their elevation. Increase may be due to more feeding of amino acids in to TCA cycle. It might be a compensatory phenomenon for the decreased mitochondrial oxidation.Resembling results with that of current study were observed in freshwater mussel Lamellidens marginalis exposed to dichlorvos (Srinivas Moorthy et al., 1986). Similar reports were recorded by Reddy et al (1985) in fresh water mussel exposed to mercury and copper. Kabeer et al (1977), reported enhanced activity of above enzymes in snail Pila globosa exposed to malathion.

\section{CONCLUSION}

Increase enzyme levels might be indicated the more conversion of amino acid into ketoacid to be utilized for energy synthesis. Increase 
activity clearly indicates that the amino acids were spread initially and when the sustained demands diminished the reverse glycogen store and amino acids were drawn into energy metabolism.

\section{REFERENCES:}

Bakthavathsalam, R. and R.Y. Srinivasa (1982) Intoxication effects of lindane (BHD) on the achrilles of aspartate and alanine amino transferase of Anabas testudineus (Bloch). Pest. Biochem. Physiol. 18:226-234.

Bakry, F.A., El-homossany, K. and Abd El Atti, M.S. and Ismaiel, S.M. (2013). Alterations in the fatty acid profile, antioxidant enzymes and protein pattern of Biomphalariaalexandrina snails exposed to the pesticides diazinon and profenofos. Global J Pharm.Pharmacol 1(1):27-36.

Ballesteros M, Durando P, Nores M, Díaz M, Bistoni M, Wunderlin D. Endosulfan induces changes in spontaneous swimming activity and acetylcholinesterase activity of Jenynsia multidentata (Anablepidae, Cyprinodontiformes) Environ Pollut. 2009;157:1573-1580.

Holden, A.V. (1973) : Effect of pesticides on Fish. Environmental pollution by pesticides (ed) C.A. In Edwards Plenum Press, London.

Kabir, I.S., Jagannath Rao, K.S. and K.V. Ranna Rao (1981) : Effects of malathion exposure on some physiological parameters of whole body of tissue ations of teleost Tilapia mossambica. J.Biol.Sci. 17-21

Kumar N, Jadhao S, Chandan N, Kumar K, Jha A, Bhushan S, et al. Dietary choline, betaine and lecithin mitigates endosulfan-induced stress in Labeo rohita fingerlings. Fish Physiol Biochem. 2012;38:9891000.

Narra Madhusudan Reddy, Begum, G., Rajender, K., Rao, J.V. (2012) Toxic impact of two organophosphate insecticides on biochemical Journal of Stress Physiology \& Biochemistry, Vol. 9 No. 2 2013, pp. 219-231 ISSN 19970838

Ravinde Reddy, T. and N. Chari (1985) : Effect of sublethal concentration of mercury and copper on AIAT, AAT and GOD of freshwater mussel Pareysia rugosa. J. Env. Biol. 6 :6770.

Satapathy, N.K.. Fatel, 8.D. and 3.K. Patnaik 1198s8) : effect of cases the respiratory metabolism of brain of Channa punctatus. Mets and Poll. 171-175.

Sivaprasada Rao, K., Satya Prasad, K. and K.V. Ramana Rao (1980) : Sublethal effect of methyl parathion o.. tissue proteolysis in the freshwater mussel, Lamellidens marginalis (Limark). Proc. Indian Sci. Acad. 164-167.

Srinivasa-Moorthy, K. (1986)Dichlorvos induced metabolic changes in tissue of fresh water mussel, Lamellidens marginalis. J.Environ. Biol. 7 :101106. 
Srinivasulu Reddy, M., Venkateshwarlu, V., Surendranath, P. and K.V. Ramana Rao (1985) : Changes in the nitrogen metabolism in the selected tissues of a penaeid prawn. Prawn Penaeus indicus exposed tophosphamidon. Environ. and Ecology. 3 :501-503.

Table 1.1 Changes in hepatopancreas protease activity of some aquatic organisms exposed to endosulfan lethal and sublethal concentrations at different exposure period. ( $\mathrm{u}$ mol of tyrosine/gm equivalent/mg protein/h)

\begin{tabular}{|c|c|c|c|c|c|c|}
\hline & \multicolumn{3}{|c|}{ Lethal (mg/1) } & \multicolumn{3}{|c|}{ sublethal(mg/l) } \\
\hline $\begin{array}{c}\text { Concentratio } \\
n\end{array}$ & 0.121 & 0.13 & 0.048 & 0.04 & 0.043 & 0.162 \\
\hline $\begin{array}{l}\text { Exposure } \\
\text { period (h) }\end{array}$ & $\begin{array}{c}\text { p.jacquem } \\
\text { ontii }\end{array}$ & $\begin{array}{l}\text { c. ori- } \\
\text { entalis }\end{array}$ & $\begin{array}{c}\text { B. } \\
\text { bengalensi } \\
\mathrm{s} \\
\text { f. typica } \\
\end{array}$ & $\begin{array}{l}\text { p.jacquem } \\
\text { ontii }\end{array}$ & $\begin{array}{l}\text { c. ori- } \\
\text { entalis }\end{array}$ & $\begin{array}{c}\text { B. } \\
\text { bengalensi } \\
\text { s } \\
\text { f. typica } \\
\end{array}$ \\
\hline Control & $\begin{aligned} & 1.03 \\
+ & -0.68\end{aligned}$ & $\begin{aligned} & 1.99 \\
+ & -0.88\end{aligned}$ & $\begin{array}{c}0.97 \\
+-0.32\end{array}$ & $\begin{aligned} & 1.03 \\
+ & -0.49\end{aligned}$ & $\begin{aligned} & 1.19 \\
+ & -0.37\end{aligned}$ & $\begin{array}{c}0.97 \\
+-0.22\end{array}$ \\
\hline 24 & $\begin{array}{c}1.23^{*} \\
+-0.33 \\
(18.29)\end{array}$ & $\begin{array}{l}1.09^{* * *} \\
+-0.49 \\
(-8.27)\end{array}$ & $\begin{array}{l}1.12^{* *} \\
+-0.13 \\
(15.28)\end{array}$ & $\begin{array}{l}1.20^{* * *} \\
+-0.33 \\
(16.11)\end{array}$ & $\begin{array}{c}1.10^{* *} \\
+-0.23 \\
(-6.89)\end{array}$ & $\begin{aligned} & 1.08^{*} \\
&+-0.92 \\
&(13.27)\end{aligned}$ \\
\hline 48 & $\begin{array}{c}1.41^{*} \\
+-0.17 \\
(35.71)\end{array}$ & $\begin{array}{l}1.66^{* *} \\
+-0.33 \\
(39.26)\end{array}$ & $\begin{array}{l}1.29 * * \\
+-0.22 \\
(32.79)\end{array}$ & $\begin{array}{l}1.38^{* *} \\
+-0.17 \\
(33.28)\end{array}$ & $\begin{array}{l}1.64^{* *} \\
+-0.63 \\
(37.30)\end{array}$ & $\begin{array}{c}1.26^{* *} \\
+-0.86 \\
(29.62)\end{array}$ \\
\hline 72 & $\begin{array}{c}1.51 \\
+-0.01 \\
(46.39)\end{array}$ & $\begin{array}{l}1.86^{*} \\
+-0.17 \\
(56.18)\end{array}$ & $\begin{array}{c}1.40 * * \\
+-0.30 \\
(44.69)\end{array}$ & $\begin{array}{c}1.49 * * \\
+-0.01 \\
(44.86)\end{array}$ & $\begin{array}{l}1.84^{* *} \\
+-0.86 \\
(54.08)\end{array}$ & $\begin{array}{c}1.37^{* *} \\
+-0.52 \\
(41.59)\end{array}$ \\
\hline 96 & $\begin{array}{l}1.61 \mathrm{~ns} \\
+-0.28 \\
(56-39)\end{array}$ & $\begin{array}{l}2.01^{* *} \\
+-0.01 \\
(69.33)\end{array}$ & $\begin{array}{c}1.47^{* *} \\
+-0.46 \\
(51.27)\end{array}$ & $\begin{array}{c}1.58 \\
+-0.27 \\
(53.61)\end{array}$ & $\begin{array}{c}1.99^{* *} \\
+-0.56 \\
(66.72)\end{array}$ & $\begin{array}{c}1.46^{* *} \\
+-0.68 \\
(49.21)\end{array}$ \\
\hline
\end{tabular}

${ }^{*} \mathrm{P}=0.01,{ }^{* *} \mathrm{P}=0.001,{ }^{* * *} \mathrm{P}=0.05, \mathrm{NS}=$ Not Significant
Sunati, V.P., Rajeswari, K., Reddy, D.C. and K.S. Swami (1989) : Impact of endosulfan on protein metabolism of the freshwater crab Oziotelphusa senex senex. Environment and Ecology, $7: 199-201$. 
Table 1.2 Changes in hepatopancreas Glutamate dehydrogenase activity of some aquatic organisms exposed to endosulfan lethal and sublethal concentrations at different exposure period. (u mol of tyrosine/gm equivalent/mg protein/h)

\begin{tabular}{|c|c|c|c|c|c|c|}
\hline & \multicolumn{3}{|c|}{ Lethal (mg/1) } & \multicolumn{3}{|c|}{ sublethal(mg/l) } \\
\hline $\begin{array}{c}\text { Concentr } \\
\text { ation }\end{array}$ & 0.121 & 0.13 & 0.048 & 0.04 & 0.043 & 0.162 \\
\hline $\begin{array}{l}\text { Exposur } \\
\text { e period } \\
\text { (h) }\end{array}$ & $\begin{array}{l}\text { p.jacque } \\
\text { montii }\end{array}$ & $\begin{array}{l}\text { c. ori- } \\
\text { entalis }\end{array}$ & $\begin{array}{c}\text { B. } \\
\text { bengalensis } \\
\text { f. typica }\end{array}$ & p.jacquemontii & c. ori-entalis & $\begin{array}{c}\text { B. } \\
\text { bengalensis } \\
\text { f. typica }\end{array}$ \\
\hline Control & $\begin{array}{c}2.18 \\
+\quad-0.19\end{array}$ & $\begin{aligned} & 2.23 \\
+ & -0.64\end{aligned}$ & $\begin{array}{c}0.61 \\
+-0.26\end{array}$ & $\begin{aligned} & 2.18 \\
+ & -0.17\end{aligned}$ & $\begin{array}{c}2.23 \\
+-0.49\end{array}$ & $\begin{array}{c}0.61 \\
+-0.56\end{array}$ \\
\hline 24 & $\begin{array}{c}2.60^{*} \\
+-0.33 \\
(19.27)\end{array}$ & $\begin{array}{l}2.05^{* * *} \\
+-0.49 \\
(-8.01)\end{array}$ & $\begin{array}{l}0.71^{* *} \\
+-0.27 \\
(17.68)\end{array}$ & $\begin{array}{l}2.57 \mathrm{~ns} \\
+-0.91 \\
(18.03)\end{array}$ & $\begin{array}{l}2.09^{* * *} \\
+-0.33 \\
(-6.23)\end{array}$ & $\begin{array}{c}0.70 * * \\
+-0.38 \\
(15.59)\end{array}$ \\
\hline 48 & $\begin{array}{l}2.86^{*} \\
+-0.17 \\
(31.57)\end{array}$ & $\begin{array}{l}3.14^{* * *} \\
+-0.33 \\
(41.11)\end{array}$ & $\begin{array}{c}0.78^{* *} \\
+-0.22 \\
(28.20)\end{array}$ & $\begin{array}{c}2.84^{*} \\
+-0.49 \\
(30.12)\end{array}$ & $\begin{array}{c}3.1^{*} \\
+-0.17 \\
(39.22)\end{array}$ & $\begin{array}{c}0.76^{* *} \\
+-0.22 \\
(26.18)\end{array}$ \\
\hline 72 & $\begin{array}{l}3.17 \mathrm{~ns} \\
+-0.88 \\
(45.62)\end{array}$ & $\begin{array}{l}3.51^{*} \\
+-0.17 \\
(57.69)\end{array}$ & $\begin{array}{c}0.86^{* *} \\
+-0.32 \\
(42.60)\end{array}$ & $\begin{array}{l}3.13^{* * *} \\
+-0.33 \\
(43.51)\end{array}$ & $\begin{array}{c}3.47^{* *} \\
+-0.01 \\
(55.62)\end{array}$ & $\begin{array}{l}0.85^{* *} \\
+-0.92 \\
(40.10)\end{array}$ \\
\hline 96 & $\begin{array}{l}3.36^{* *} \\
+-0.17 \\
(54.29)\end{array}$ & $\begin{array}{l}3.68 \mathrm{~ns} \\
+-0.01 \\
(65.32)\end{array}$ & $\begin{array}{l}0.92^{* *} \\
+-0.25 \\
(51.62)\end{array}$ & $\begin{array}{c}3.32^{*} \\
+-0.17 \\
(52.37)\end{array}$ & $\begin{array}{l}3.64 \\
+-0.28 \\
(63.29)\end{array}$ & $\begin{array}{l}0.90^{* *} \\
+-0.86 \\
(48.37)\end{array}$ \\
\hline
\end{tabular}

${ }^{*} \mathrm{P}=0.01,{ }^{*} \mathrm{P}=0.001,{ }^{* *} \mathrm{P}=0.05, \mathrm{NS}=$ Not Significant 
Table 1.3 Changes in Liver/Hp Aspartate aminotransferase activity of some aquatic organisms exposed to endosulfan lethal and sublethal concentrations at different exposure period. (u mol of tyrosine/gm equivalent/mg protein/h)

\begin{tabular}{|c|c|c|c|c|c|c|}
\hline & \multicolumn{3}{|c|}{ Lethal (mg/l) } & \multicolumn{3}{|c|}{ sublethal(mg/l) } \\
\hline Concentration & 0.121 & 0.13 & 0.048 & 0.04 & 0.043 & 0.162 \\
\hline $\begin{array}{l}\text { Exposure } \\
\text { period (h) }\end{array}$ & p.jacquemontii & $\begin{array}{l}\text { c. ori- } \\
\text { entalis }\end{array}$ & $\begin{array}{c}\text { B. } \\
\text { bengalensis } \\
\text { f. typica }\end{array}$ & $\begin{array}{l}\text { p.jacquem } \\
\text { ontii }\end{array}$ & c. ori-entalis & $\begin{array}{c}\text { B. } \\
\text { bengalensis } \\
\text { f. typica }\end{array}$ \\
\hline Control & $\begin{array}{c}2.04 \\
+-0.99\end{array}$ & $\begin{aligned} & 2.24 \\
+ & -0.88\end{aligned}$ & $\begin{array}{c}1.87 \\
+-0.26\end{array}$ & $\begin{array}{c}2.04 \\
+-0.49\end{array}$ & $\begin{aligned} & 2.24 \\
+ & -0.56\end{aligned}$ & $\begin{aligned} & 1.87 \\
+ & -0.32\end{aligned}$ \\
\hline 24 & $\begin{array}{c}2.48 \\
+-0.88 \\
(21.69)\end{array}$ & $\begin{array}{l}2.06^{* * *} \\
+-0.64 \\
(-7.69)\end{array}$ & $\begin{array}{l}2.17^{* *} \\
+-0.27 \\
(15.98)\end{array}$ & $\begin{array}{l}2.42^{* * *} \\
+-0.33 \\
(18.64)\end{array}$ & $\begin{array}{c}2.09 * * \\
+-0.38 \\
(-6.87)\end{array}$ & $\begin{array}{l}2.15^{* *} \\
+-0.13 \\
(14.92)\end{array}$ \\
\hline 48 & $\begin{array}{l}2.81^{* * *} \\
+-0.64 \\
(37.67)\end{array}$ & $\begin{array}{l}3.13^{* * *} \\
+-0.49 \\
(39.69)\end{array}$ & $\begin{array}{c}2.42 * * \\
+-0.22 \\
(30.65)\end{array}$ & $\begin{array}{c}2.75^{*} \\
+-0.17 \\
(34.61)\end{array}$ & $\begin{array}{c}3.08^{* *} \\
+-0.22 \\
(37.16)\end{array}$ & $\begin{array}{c}2.41^{* *} \\
+-0.22 \\
(28.62)\end{array}$ \\
\hline 72 & $\begin{array}{l}2.97^{* * *} \\
+-0.49 \\
(46.78)\end{array}$ & $\begin{array}{c}3.46^{*} \\
+-0.33 \\
(54.29)\end{array}$ & $\begin{array}{c}2.63 * * \\
+-0.32 \\
(41.62)\end{array}$ & $\begin{array}{c}2.89 * * \\
+-0.01 \\
(43.72)\end{array}$ & $\begin{array}{c}3.36^{* *} \\
+-0.92 \\
(50.21)\end{array}$ & $\begin{array}{c}2.59 * * \\
+-0.30 \\
(39.61)\end{array}$ \\
\hline 96 & $\begin{array}{l}3.08^{* * *} \\
+-0.33 \\
(51.09)\end{array}$ & $\begin{array}{l}3.69^{* *} \\
+-0.17 \\
(64.83)\end{array}$ & $\begin{array}{l}2.78^{* *} \\
+-0.25 \\
(48.69)\end{array}$ & $\begin{array}{l}3.04 \mathrm{~ns} \\
+-0.68 \\
(49.04)\end{array}$ & $\begin{array}{c}3.62^{* *} \\
+-0.86 \\
(61.80)\end{array}$ & $\begin{array}{c}2.74 * * \\
+-0.46 \\
(46.63)\end{array}$ \\
\hline
\end{tabular}

${ }^{*} \mathrm{P}=0.01,{ }^{* *} \mathrm{P}=0.001,{ }^{* * *} \mathrm{P}=0.05, \mathrm{NS}=$ Not Significant 
Table 1.4 Changes in hepatopancreas Alanine aminotransferase activity of some aquatic organisms exposed to endosulfan lethal and sublethal concentrations at different exposure period. (u mol of tyrosine/gm equivalent/mg protein/h)

\begin{tabular}{|c|c|c|c|c|c|c|}
\hline & \multicolumn{3}{|c|}{ Lethal (mg/l) } & \multicolumn{3}{|c|}{ sublethal(mg/1) } \\
\hline Concentration & 0.121 & 0.13 & 0.048 & 0.04 & 0.043 & 0.162 \\
\hline $\begin{array}{l}\text { Exposure } \\
\text { period (h) }\end{array}$ & p.jacquemontii & $\begin{array}{l}\text { c. ori- } \\
\text { entalis }\end{array}$ & $\begin{array}{c}\text { B. } \\
\text { bengalensis } \\
\text { f. typica }\end{array}$ & p.jacquemontii & $\begin{array}{l}\text { c. ori- } \\
\text { entalis }\end{array}$ & $\begin{array}{c}\text { B. } \\
\text { bengalensis } \\
\text { f. typica }\end{array}$ \\
\hline Control & $\begin{array}{c}3.15 \\
+-2.62\end{array}$ & $\begin{aligned} & 3.47 \\
+ & -0.99\end{aligned}$ & $\begin{aligned} & 3.02 \\
+ & -0.88\end{aligned}$ & $\begin{array}{l}3.15 \\
+-0.56\end{array}$ & $\begin{aligned} & 3.47 \\
+ & -0.49\end{aligned}$ & $\begin{array}{c}3.02 \\
+-0.64\end{array}$ \\
\hline 24 & $\begin{array}{l}3.87^{* *} \\
+-2.71 \\
(23.37)\end{array}$ & $\begin{array}{l}8.19^{*} \\
+-0.49 \\
(-8.02)\end{array}$ & $\begin{array}{l}3.45^{* * *} \\
+-0.64 \\
(14.37)\end{array}$ & $\begin{array}{l}3.83^{* *} \\
+-0.38 \\
(21.52)\end{array}$ & $\begin{array}{l}3.21^{* * *} \\
+-0.33 \\
(-7.89)\end{array}$ & $\begin{array}{l}3.39^{* * *} \\
+-0.49 \\
(12.09)\end{array}$ \\
\hline 48 & $\begin{array}{l}4.40 * * \\
+-2.23 \\
(39.62)\end{array}$ & $\begin{array}{l}4.90^{* * *} \\
+-3.01 \\
(41.27)\end{array}$ & $\begin{array}{l}3.92^{* * *} \\
+-0.49 \\
(29.91)\end{array}$ & $\begin{array}{l}4.33^{* *} \\
+-0.22 \\
(37.53)\end{array}$ & $\begin{array}{l}4.83 \mathrm{~ns} \\
+-0.42 \\
(39.22)\end{array}$ & $\begin{array}{c}3.84^{* * *} \\
+-0.33 \\
(27.21)\end{array}$ \\
\hline 72 & $\begin{array}{l}4.56^{* *} \\
+-3.20 \\
(46.29)\end{array}$ & $\begin{array}{l}5.39 * * \\
+-3.91 \\
(55.36)\end{array}$ & $\begin{array}{l}4.18^{* * *} \\
+-0.33 \\
(38.61)\end{array}$ & $\begin{array}{l}4.47^{* * *} \\
+-0.92 \\
(44.27)\end{array}$ & $\begin{array}{l}5.31^{* *} \\
+-0.33 \\
(53.16)\end{array}$ & $\begin{array}{l}4.13 \mathrm{~ns} \\
+-0.56 \\
(36.82)\end{array}$ \\
\hline 96 & $\begin{array}{l}4.84^{* *} \\
+-2.51 \\
(53.66)\end{array}$ & $\begin{array}{r}5.80 * * \\
+-3.80 \\
(67.09)\end{array}$ & $\begin{aligned} & 4.37^{*} \\
&+-0.17 \\
&(44.69)\end{aligned}$ & $\begin{array}{l}4.79 * * \\
+-0.52 \\
(52.10)\end{array}$ & $\begin{aligned} & 5.77^{*} \\
&+-0.17 \\
&(66.28)\end{aligned}$ & $\begin{array}{l}4.29 * * \\
+-0.38 \\
(42.11)\end{array}$ \\
\hline
\end{tabular}

. ${ }^{*} \mathrm{P}=0.01,{ }^{* *} \mathrm{P}=0.001,{ }^{* * *} \mathrm{P}=0.05, \mathrm{NS}=$ Not Significant 